\title{
Mesowear Analysis of the Tapirus polkensis population from the Gray Fossil Site, Tennessee, USA
}

\author{
Julia A. Schap and Joshua X. Samuels
}

\begin{abstract}
Various methods exist for measuring and analyzing dental wear patterns in mammals, and these patterns have been extensively studied in ungulates. Mesowear has proven useful as a method to compare large numbers of individuals, particularly fossil individuals, observe trends through time or between groups, and estimate paleoenvironmental conditions. Levels of attrition (tooth-on-tooth wear) and abrasion (tooth-onfood wear) can be readily compared by observing the shape of the cusp and relative crown height of the tooth. This study uses a modified method of mesowear analysis, examining actual cusp angles of the population of Tapirus polkensis from the Gray Fossil Site, a densely canopied, hickory and oak dominated forest located in Gray, Tennessee. Crown height and cusp angle were measured for 38 specimens arranged into eruption series from young juveniles to old adults. Results found a strong correlation between eruption series and cusp angle with a steady increase in mean angle as the individuals increase in age. A strong correlation between cusp angle and crown height was also found. Overall, the population showed relatively low wear rates, as would be expected of a forest-dwelling browser. As a mesowear analysis across all age groups for a population has not been conducted before, this study could be useful for measuring relative wear rates at different life stages and could be applied across other communities.
\end{abstract}

Julia A. Schap. Don Sundquist Center for Excellence in Paleontology, Department of Geosciences, East Tennessee State University, Johnson City, Tennessee, 37614 USA. jschap3@gatech.edu

Currently: School of Biological Sciences, Georgia Institute of Technology, Atlanta, Georgia, 30332, USA Joshua X. Samuels. Don Sundquist Center for Excellence in Paleontology, Department of Geosciences, East Tennessee State University, Johnson City, Tennessee, 37614 USA. samuelsjx@etsu.edu

Keywords: Tapiridae; Pliocene; mesowear; Tennessee, dental wear

Submission: 10 April 2018. Acceptance: 21 May 2020.

Schap, Julia A. and Samuels, Joshua X. 2020. Mesowear Analysis of the Tapirus polkensis population from the Gray Fossil Site, Tennessee, USA. Palaeontologia Electronica, 23(2):a26. https://doi.org/10.26879/875

palaeo-electronica.org/content/2020/3054-tapir-population-mesowear

Copyright: May 2020 Society of Vertebrate Paleontology.

This is an open access article distributed under the terms of the Creative Commons Attribution License, which permits unrestricted use, distribution, and reproduction in any medium, provided the original author and source are credited. creativecommons.org/licenses/by/4.0 


\section{INTRODUCTION}

Living perissodactyls include three ecologically divergent ungulate families: horses (Equidae), rhinos (Rhinocerotidae), and tapirs (Tapiridae). Tapirs are relatively large, forest-dwelling browsers characterized by a mobile proboscis, which is used for sensing the environment and helping with consumption and manipulation of vegetation (Macdonald, 1985). Four extant species of tapirs are known: Tapirus bairdii (Baird's Tapir), T. indicus (Malaysian Tapir), T. pinchaque (Mountain Tapir), and T. terrestris (Brazilian or Lowland Tapir) (Wilson and Reeder, 2005) (the recently described T. kabomani from the Amazon may represent a fifth species [Cozzuol et al., 2013], but its distinction from T. terrestris has been questioned [Ruiz-García et al., 2016]). Tapirus also includes multiple extinct species demonstrating a historically broader geographic range for this genus, such as the North American T. polkensis (Hulbert, 2005). Tapirus polkensis was a relatively small tapir, the largest sample of which is known from the early Pliocene Gray Fossil Site (GFS) in eastern Tennessee, which records over 75 individuals from various age groups (Hulbert et al. 2009; Gibson, 2011). Average body mass estimated for T. polkensis is $125 \mathrm{~kg}$ compared to extant $T$. terrestris at $184 \mathrm{~kg}, T$. bairdii at $223 \mathrm{~kg}$, and $T$. indicus at $287 \mathrm{~kg}$ (Hulbert et al., 2009). The relationships of $T$. polkensis have been debated, with it previously having been placed in the genus Tapiravus until Hulbert et al. (2009) concluded that this species belonged in Tapirus based on a thorough morphological study of skulls, mandibles, and cheek teeth. Outside of Tennessee, $T$. polkensis is also known from Mio-Pliocene localities in Florida (including the type locality in Polk County; Olsen, 1960).

The GFS is the only pre-Pleistocene Cenozoic vertebrate fossil locality found within the Appalachian region of the eastern US, and a wide variety of paleoflora and fauna have been discovered there (including fish, amphibians, reptiles, birds, mammals, and invertebrates; see Wallace and Wang, 2004; Hulbert et al. 2009). Most published studies on the GFS have examined the taxonomic diversity represented in this site, but the exceptional sample size of certain fossil taxa (notably $T$. polkensis) also permits intraspecific community level observations, as specimens from many age groups have been discovered.

For many decades, mammalian dental morphology has been studied not only to provide information about what individual species were eating, but also to provide insight into other aspects of local ecology. On a broad scale, dental morphology can generally distinguish between carnivores, herbivores, and omnivores (for example, Janis, 1988; Van Valkenburgh, 1989; Janis, 1995; Mendoza et al., 2002; Evans et al., 2007). More refined examinations of dental morphology can reveal specific diets within a community and how diet may vary within a species depending on where it lived and what resources were available (Hoffman et al, 2015). Herbivores are trophically closely tied to their environments, and therefore fossil herbivore teeth are widely used to help reconstruct their feeding behaviors and paleoenvironments (Fortelius and Solounias, 2000). Herbivores typically display blunt, blocky teeth compared to carnivores, with broad, complexly-cusped biting surfaces that help them to process and digest fibrous plants, which commonly require more chewing cycles per food volume than animal remains (Ungar, 2015).

Gross and microscopic levels of tooth wear are often examined to reconstruct feeding behavior of extinct animals (Ungar, 2015). Mesowear analyses (the study of macroscopic wear facets on dentition) examine tooth wear to characterize the average diet of a population (Fortelius and Solounias, 2000; Mihlbachler et al., 2011). Mesowear reveals the amounts of attrition (toothon-tooth) wear, which forms facets on teeth, and abrasion (food-on-tooth wear), which obliterates tooth material, that occurred while the individual ate (Mihlbachler et al., 2011; Ungar, 2015; Green and Croft, 2018). Ungulates typically exhibit stability in wear throughout their life, except for the earliest and latest stages of their lives (Fortelius and Solounias, 2000). The complete herbivorous dietary spectrum, ranging from browsing to mixedfeeding and grazing, can be distinguished through studying mesowear with cusp height and sharpness (Andrews and Hixson, 2014; Ungar, 2015). Browsers (defined as herbivores consuming $<10 \%$ grasses in their diet) typically maintain sharpened, high-relief cusp apices with low dental wear rates when compared to grazers (>90\% grasses in diet), who consume abrasive, phytolith-bearing grasses covered in grit (Hofmann and Stewart, 1972; Mihlbachler et al., 2011; Damuth and Janis, 2014; Green and Croft, 2018).

Fortelius and Solounias (2000) established a method of studying mesowear in ungulates that has been the basis of many subsequent studies. Their study involved the classification of tooth cusp apices into categories of sharp, rounded, or blunt and categorizing relief (valley between cusps and distance between cusps) as low or high. Over time, 
this method has been extensively used, with new variations and additions to the underlying protocol being incorporated as more dentally novel groups are analyzed. While various scoring systems have been employed in mesowear studies, most have differed subtly (Green and Croft, 2018). Fraser et al. (2014) added a new mesowear score in their study of ruminants, expanding the original system which scored only from 0-3. Mihlbachler et al. (2011) created a mesowear index ranging from 17 , made specifically for their study of Equidae. Other recent studies of mesowear have broadened its application to include groups outside its original ungulate focus, including analyses of small mammals (Ulbricht et al., 2015) and marsupials (Butler et al., 2014). One recent variant method developed by Solounias et al. (2014), and utilized by Danowitz et al. (2016), focused on wear on the inner portions of teeth in selenodont artiodactyls. Another variant method measured occlusal wear angles in proboscideans (Saarinen et al., 2015; Saarinen and Lister, 2016) and xenarthrans (Saarinen and Karme, 2017) as a means of dietary analysis.

Studying diets through mesowear is important because while base dental morphology reflects what the animal was capable of eating, it does not tell us what individuals were actually eating on a daily basis, given variable environments and available vegetation, which can provide a much clearer picture of past communities (Ungar, 2015). Overall tooth morphology is hereditary, but tooth wear occurs during the lives of individuals, so wear patterns reflect local ecology and preferred diet at that specific locality (Fortelius and Solounias, 2000; Green and Croft, 2018). Comparisons of mesowear in populations can help to reveal important environmental characteristics, which may not be evident based simply on the occurrences or abundances of taxa.

Seven life history stages have been assigned to the GFS Tapirus polkensis sample based on eruption sequence of teeth and wear of those teeth (Hulbert et al., 2009). Further study of the tapirs at the GFS gave rise to age groups associated with those life history stages (Gibson, 2011). These age groups were based on a study of $T$. bairdii by the Baird's Tapir Project of Costa Rica, which included information on eruption sequence from individuals one to seven years old (Gibson, 2011). Eruption occurs at relatively predictable intervals, so wear shown between teeth corresponds to a fixed time period consistent across the whole species (Ungar, 2015).
With an unparalleled sample of Tapirus polkensis, the GFS is an ideal site to examine possible trends in mesowear throughout the life history of a population. By examining mesowear at various ages of these tapirs, periods of escalated or decreased wear may be measurable in ways that have not been studied before in a fossil population. Correlations between wear and age class may also be determined and may be a useful proxy for similar studies on a variety of extinct species.

\section{MATERIALS AND METHODS}

A total of 38 Tapirus polkensis dentaries were studied from the Gray Fossil Site (full list in Appendix 1), all of which are housed in the collections of the East Tennessee State University Museum of Natural History (ETMNH). Terminology for the studied dentition is designated as follows: $p=$ premolar, $\mathrm{m}=$ molar, and $\mathrm{d}=$ deciduous. Specimens included in the study were chosen based on eruption and measurability of the lower $\mathrm{m} 1$. Any individuals with only half of the $\mathrm{m} 1$ present were discarded from the study, as they do not provide an accurate total length and were often missing the protoconid cusp examined in the study. Specimens where the $\mathrm{m} 1$ was obliterated were excluded, as it cannot be determined whether the tooth was damaged from wear in life or if it was broken post-mortem. Left dentaries were preferred; however, three right dentaries were used due to the left dentary not being recovered for that individual. It is assumed that the same wear rate would be seen on both sides of the mandible, qualitative observations of complete mandibles at the site found little to no difference in wear on either side of the tooth row, supporting that assumption. All dentaries were photographed using a Nikon D810 DSLR camera. Two views of each dentary were photographed: the lateral view, with the mandibular ramus parallel to the photographic plane, and an occlusal view with the alveolar margin of the tooth row parallel to the photographic plane. Images were analyzed using ImageJ (Rasband, 2016). All photographs and measurements were taken by one person in order to remain as consistent as possible, and to avoid inter-observer error. Total $\mathrm{m} 1$ length ( $\mathrm{m} 1 \mathrm{~L}$, taken from anterior to posterior cingulum), crown height $(\mathrm{m} 1 \mathrm{H}$, from the enamel/dentine junction to tip of the protoconid), and the angle of the protoconid cusp (m1CA, from anterior cingulum to tip of protoconid to the labial cingulum posterior to the protoconid) were measured on each specimen (Figure 1). A similar methodology, utilizing direct measurements of cusp-angles, was employed by Loffredo and 


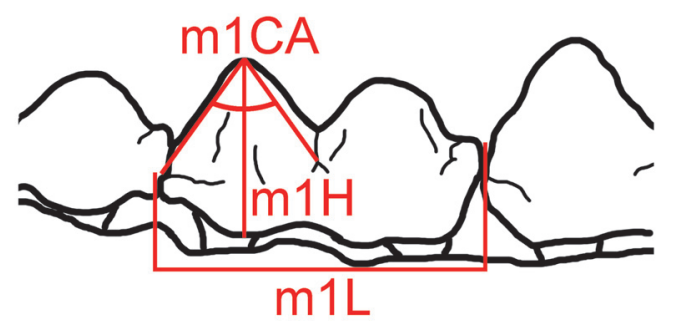

FIGURE 1. Measurements taken of the $\mathrm{m} 1$ used in this study. m1L (total molar length, taken from anterior to posterior cingulum), $\mathrm{m} 1 \mathrm{H}$ (molar height, from the enamel/dentine junction to tip of the protoconid), m1CA (cusp angle, from anterior cingulum to tip of protoconid to the labial cingulum posterior to the protoconid).

TABLE 1. Eruption series in tapirs broken down by general age classification and specific age ranges. Adapted from Gibson (2011) and Hulbert et al. (2009).

\begin{tabular}{clc}
\hline $\begin{array}{c}\text { Eruption } \\
\text { Series }\end{array}$ & Age Classification & Age Range \\
\hline 1 & Very Young Juvenile & $<1-1 \mathrm{yr}$ \\
2 & Young Juvenile & $<1-2 \mathrm{yr}$ \\
3 & Juvenile & $1-2 \mathrm{yr}$ \\
4 & Subadult & $2-4 \mathrm{yr}$ \\
5 & Young Adult & $4-9 \mathrm{yr}$ \\
6 & Full Adult & $6-9 \mathrm{yr}$ \\
7 & Old Adult & $9->11 \mathrm{yr}$ \\
\hline
\end{tabular}

DeSantis (2014) to study the mesowear of a population of the equid Cormohipparion from Florida. Direct measurement of cusp angles allows us to capture continuous variation in cusp wear and also use parametric statistics (like Analysis of Variance), in contrast to most mesowear studies, which use nonparametric tests (like Mann-Whitney Utests) due to the categorical nature of data.
Specimens were organized into Eruption Series (ES) groups according to tooth eruption and wear, based on work conducted by Gibson (2011) and Hulbert et al. (2009). Twenty-five of the specimens studied had been previously categorized by Gibson in his study. Thirteen specimens had to be newly categorized, which was done using the same dental patterns described by Gibson (2011) and Hulbert et al. (2009) (Table 1). Primary groupings are based on the cheek teeth present, with tooth wear being examined secondarily to distinguish between individuals who have already erupted p2-m3 (Table 2). ES 1 represent very young juveniles from $<1-1$ year, ES 2 represent young juveniles from $<1-2$ years, ES 3 represent juveniles from $1-2$ years, ES 4 represent subadults from $2-4$ years, ES 5 represent young adults from $4-9$ years, ES 6 represent full adults from 6 - 9 years, and ES 7 represent old adults from $9->11$ years (Gibson, 2011) (Table 1). Exposure of dentine on the $\mathrm{m} 3$ is used to differentiate old adults (ES 7) from full adults (ES 6). Individuals within Eruption Series 1 do not yet have an $\mathrm{m} 1$ and therefore they are not included in this study. Specimens examined in this study range from ES 2 up to ES 7 (old adults, which is the oldest group recognized by previous studies) (Figure 2, Figure 3). The m1 was chosen as the comparison tooth, as it erupts fairly early in tapir ontogeny and does not get replaced like the dp2-dp4, therefore representing a more accurate measure of wear across most of an individual's lifetime.

IBM SPSS Statistics 24 was used to run all statistical analyses. Univariate Analysis of Variance (ANOVA) was conducted to compare means for cusp angle and crown height among Eruption Series. Crown height and cusp angle were analyzed as dependent variables and the Eruption Series as the independent. Post Hoc analyses were performed using a Sheffe's test, which

TABLE 2. Presence and absence of lower teeth and the wear stage of the teeth at each eruption series. Adapted from Gibson (2011).

\begin{tabular}{cl}
\hline Eruption Series & \multicolumn{1}{c}{ Teeth Present/Wear Observed } \\
\hline 1 & $\mathrm{dp} 2-\mathrm{dp} 3$ no wear, dp4 may be erupting \\
2 & $\mathrm{dp} 2-\mathrm{dp} 4$ erupted, m1 may be erupting, slight wear \\
3 & $\mathrm{dp} 2-\mathrm{m}$ 1 erupted and in wear, adult premolars/molars in crypts \\
4 & $\mathrm{p} 2-\mathrm{p} 3, \mathrm{dp} 4, \mathrm{~m} 1$ erupted and in wear, m2 may be erupting, minimum wear on p2-p3, heavy wear \\
& on dp4 \\
6 & $\mathrm{p} 4$ and m2 erupted and in wear, m3 erupting or erupted with minimum wear \\
7 & $\mathrm{~m} 3$ cusps moderately worn with no dentine exposure \\
\hline
\end{tabular}



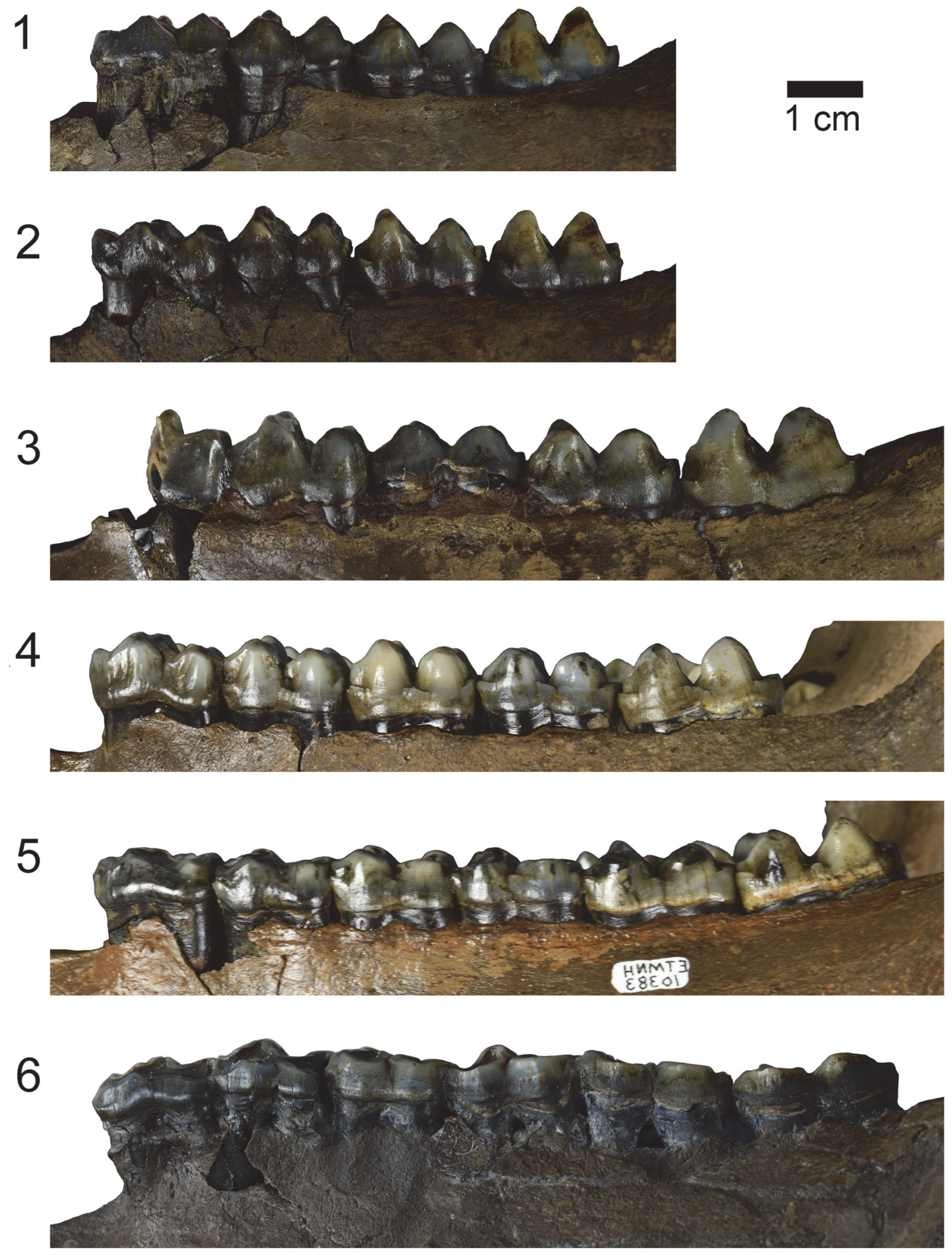

FIGURE 2. Tapirus polkensis dentary specimens from the Gray Fossil Site, representing examples of individuals within eruption series 2 through eruption series 7 in lateral view. ETMNH 605, 1. ETMNH 3694, 2. ETMNH 7899, 3. ETMNH 20488, 4. ETMNH 10383, 5. ETMNH 3519, 6. Scale bar equals $1 \mathrm{~cm}$. 


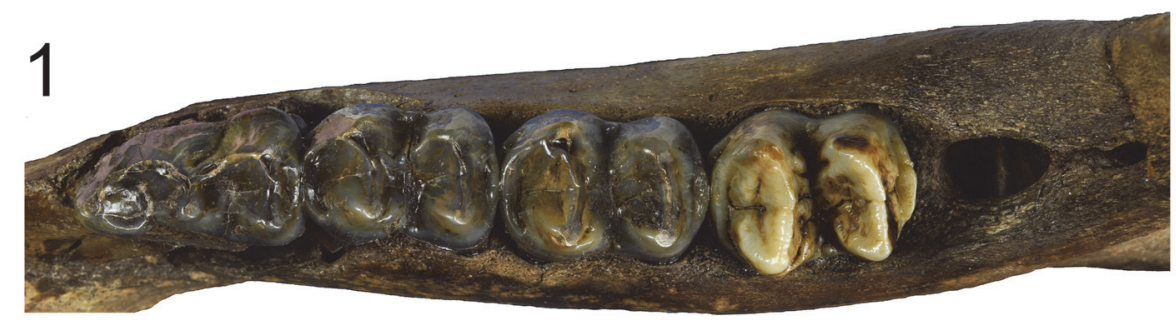

\section{$1 \mathrm{~cm}$}
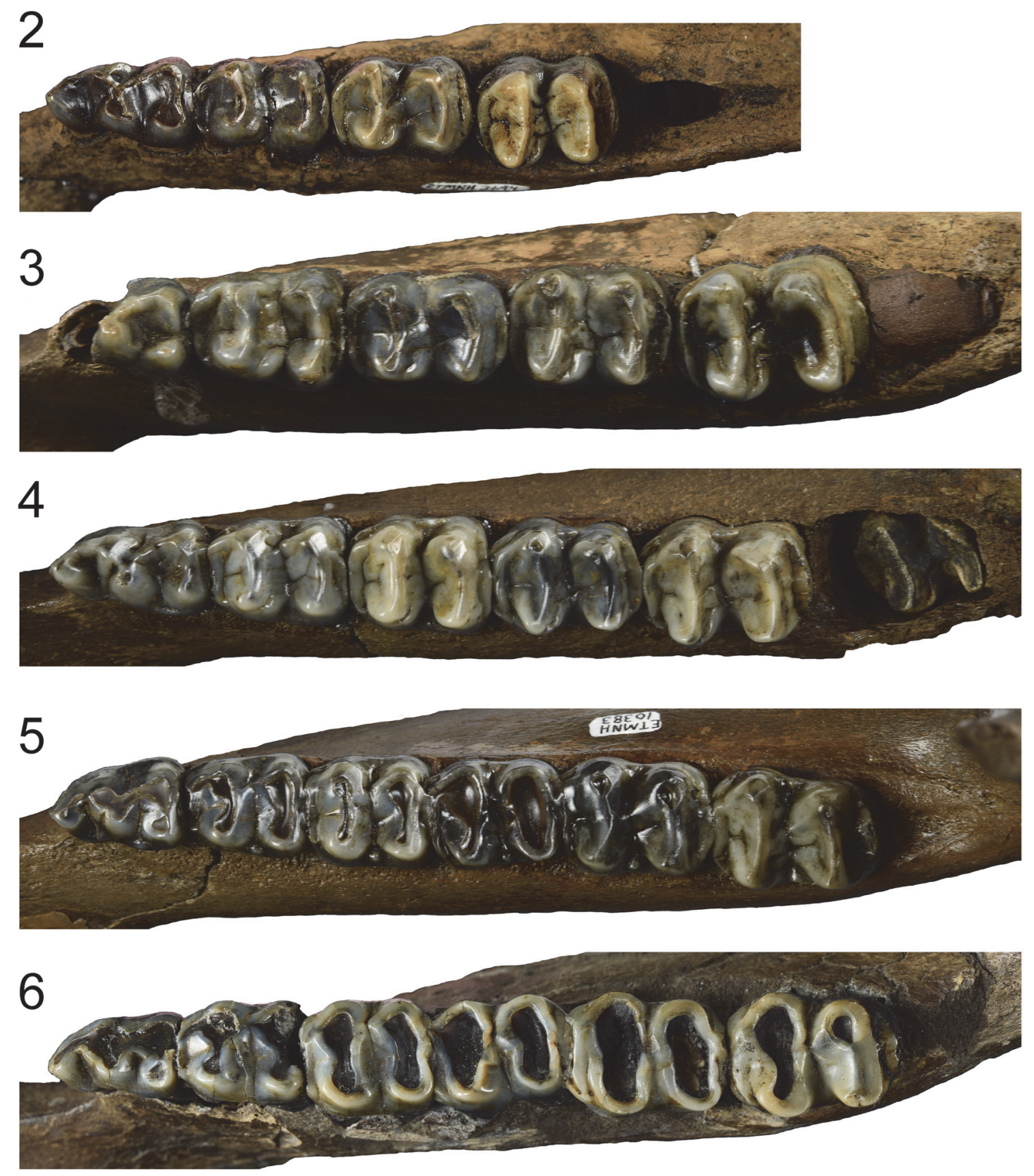

FIGURE 3. Tapirus polkensis dentary specimens from the Gray Fossil Site, representing examples of individuals within eruption series 2 through eruption series 7 in occlusal view. ETMNH 605, 1. ETMNH 3694, 2. ETMNH 7899, 3. ETMNH 20488, 4. ETMNH 10383, 5. ETMNH 3519, 6. Scale bar equals $1 \mathrm{~cm}$. 
assumes equal variances, and a Tamhane's T2 test, which does not assume equal variances. These tests can help determine if there are significant differences in mesowear, in the form of cusp angle and crown height, between ES categories of the GFS tapir population. To determine which Post Hoc test was appropriate, a Levene's test of homogeneity of variances was performed. Where variances were significantly different between ES categories, Tamhane's T2 values are reported. Linear regression analysis was also performed to examine whether cusp angle and crown height were correlated with one another.

Since the studied individuals represent many life stages found in the same population, these analyses can help reveal overall wear patterns throughout the assemblage and whether there is much variation between individuals of similar age. We predict there to be a negative relationship between crown height and cusp angle in the sample studied, with cusp angles becoming greater as attrition of the tooth crown occurs through the life of an individual. As is discussed below, the GFS is interpreted as a warm, humid forested environment in the Pliocene and thus the diets of these tapirs could represent a highly distinct ecology for the time, contrasting with the commonly studied faunas living in open and often $\mathrm{C}_{4}$ grass dominated habitats of the Great Plains and western part of North America.

\section{GEOLOGICAL SETTING}

The Gray Fossil Site (GFS) is a unique early Pliocene age paleontological site located within northeast Tennessee, which is interpreted as having formed within an ancient sinkhole with a small, deep lake (Shunk et al. 2006; 2009). Zobaa et al. (2011) concluded that the GFS is composed of multiple sinkholes and sub-basins, which preserve multiple basin-fill histories with overprinting sinkhole events. Two cores were taken at the site, GFS-1 and GFS-2 (Shunk et al., 2006; 2009; Zobaa et al., 2011). The GFS-1 core was found to be from an independent sub-basin (karst solution) containing Paleocene-Eocene palynomorphs (Zobaa et al., 2011). This core predates the GFS-2 core which is late Miocene/early Pliocene and was infilled from lacustrine (finely laminated, organic rich, silty clays and sands) sediments over the course of 4,500 to 11,000 years (Shunk et al., 2009) and was capped by fluvial deposits and paleosols. Deposits found from the GFS-2 core are similar to what covered and preserved the site (Zobaa et al., 2011).
Both flora and fauna from the site are wellpreserved and highly diverse (ex. Parmalee et al., 2002; Wallace and Wang, 2004; Mead et al., 2012; Zobaa et al., 2011; Ochoa et al., 2012; 2016; Worobiec et al., 2013; Samuels et al., 2018). Macro- and microfossils record a forest flora, which is interpreted as dominated by oak (Quercus), hickory (Carya), and pine (Pinus), along with an understory composed of various herbaceous taxa (Ochoa et al., 2016; and references therein). Analyses by Zobaa et al. (2011) also found a dominant oakhickory forest and pointed to the presence of a relatively dense canopy for a temperate forest. Some plant fossils at the site, particularly tupelo (Nyssa) and bald cypress (Taxodium) leaves and pollen, suggest humid riparian or wetland areas occurred at the site (Brandon, 2013; Worobiec et al. 2013). Based on examination of flora from the site, Ochoa et al. (2016) interpreted it as representing a woodland or wooded savanna environment characterized by frequent disturbance. DeSantis and Wallace (2008) analyzed carbon and oxygen isotopes from ungulate and proboscidean teeth from the site, finding support for the presence of relatively dense forest, though a proboscidean sample suggested grasslands may have been present somewhere in the area surrounding the GFS, at least within the range traveled by modern proboscideans. The isotopic work of DeSantis and Wallace (2008) also suggests the climate had little seasonal variation in temperature or precipitation.

A variety of faunal elements also aid in reconstructing the past environment at the site. Multiple taxa indicate the presence of aquatic environments, including fish, neotenic salamanders, aquatic turtles, Alligator, and beavers (Parmalee et al., 2002; Boardman and Schubert, 2011; Mead et al., 2012; Jasinski, 2013; Bourque and Schubert, 2015). The presence of alligators, which presently live in environments of at least $22^{\circ} \mathrm{C}$ (Markwick, 1998), and tapirs, which live in humid mesothermal (characterized by moderate heat and moisture) areas today, provides evidence for the GFS to have been warmer in the early Pliocene than currently, with minimal seasonal variation, as was suggested by isotopic analyses (DeSantis and Wallace, 2008). Other mammals at the site are characteristic of forested habitats, specifically tree squirrels, flying squirrels, and the extinct panda Pristinailurus (Wallace and Wang, 2004; Crowe, 2017). Mead et al. (2012) described specimens found at the GFS that belong to Heloderma (Gila monsters and beaded lizards), which are presently restricted to warm $\left(>24^{\circ} \mathrm{C}\right)$ subtropical deserts, 
pine-oak woodlands, and tropical deciduous forests.

Overall, both the flora and fauna at the Gray Fossil Site represent a unique combination, unlike any other biota in North America. There was a transition during the Miocene and Pliocene to more open habitats and more dominant $\mathrm{C}_{4}$ vegetation in many parts of North America (Retallack, 2007; DeSantis and Wallace, 2008; Edwards et al., 2010; Strömberg, 2011), but the GFS offers a unique view of a locality where forested habitats and animals with preference for such habitats are preserved.

A new age estimate for the Gray Fossil Site was recently published based on a number of mammal species with limited stratigraphic ranges (Samuels et al., 2018). The site includes several mammal taxa that are characteristic of Blancan faunas, and none that are restricted to the Miocene or the Hemphillian NALMA. Among the biostratigraphically informative taxa at the site are the rhino Teleoceras, dromomerycid Pediomeryx, mephitid Buisnictis breviramus, leporids Alilepus and Notolagus, and the cricetids Neotoma, Repomys, and Symmetrodontomys (Samuels et al., 2018). Based on those taxa, the age of the site is estimated to be within the early Pliocene, between 4.9 and $4.5 \mathrm{Ma}$, near the Hemphillian - Blancan transition (Samuels et al., 2018).

\section{RESULTS}

The results reveal clear differences in crown height and cusp angle among Eruption Series within the population of Tapirus polkensis. The one-way ANOVA for cusp angle showed highly significant differences between Eruption Series ( $F=$ 26.831, $p<0.001$, df $=5$ ) (Table 3). Mean cusp angles grew larger through every measured Eruption Series, with means for ES 2-7 being 69.52, $69.53,77.09,99.24,110.69$, and 159.52, respectively (Table 3 ). Every Eruption Series was signifi-

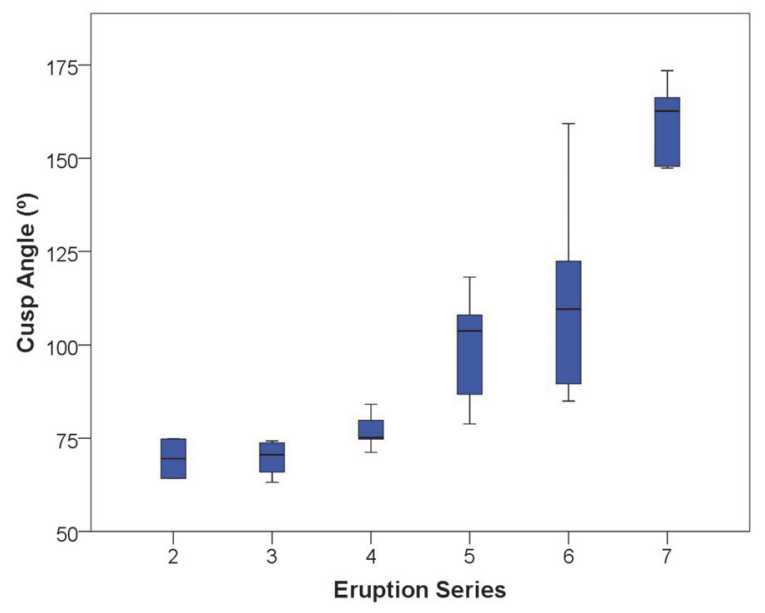

FIGURE 4. Box plot of cusp angles (in degrees) of the $\mathrm{m} 1$ protoconid for each eruption series of Tapirus polkensis from the Gray Fossil Site. Bars represent mean values, boxes represent interquartile ranges, and whiskers represent maximum and minimum values.

cantly different from ES 7. Eruption Series 2, 3, 4, and 7 were also significantly different from ES 6 . Eruption Series 2 and 3 displayed relatively unworn premolars and an unworn $\mathrm{m} 1$. Eruption Series 4 and 5 showed varying stages of wear, depending in part on whether they had lost the deciduous premolars (dp2, dp3, dp4). By ES 6, many individuals had exposed dentine, causing cusps to flatten, on multiple teeth, while all teeth had exposed dentine by ES 7 (Figure 4).

The one-way ANOVA for crown height $(\mathrm{mm})$ showed highly significant differences between Eruption Series $(F=24.975, p=0.00, d f=5)$ (Table 3). Crown height means decreased with each progressive Eruption Series. Eruption Series 2-7 had means of 11.16, 10.30, 9.60, 7.67, 6.99, and $4.06(\mathrm{~mm})$, respectively. As for cusp angle, crown height of every Eruption Series was significantly different from ES 7. Eruption Series 2 and 3

TABLE 3. Mean values and standard deviations for cusp angle $(m 1 C A)$ and crown height $(m 1 \mathrm{H})$ for each eruption series of Tapirus polkensis from the Gray Fossil Site. Data are reported as follows: Mean (Standard Deviation). Significant differences between eruption series in univariate ANOVA tests at the $p<0.05$ level using Tamhane's T2 post hoc procedure are indicated by superscript values.

\begin{tabular}{ccccccc}
\hline & \multicolumn{5}{c}{ Eruption Series } \\
& $\mathbf{2}$ & $\mathbf{3}$ & $\mathbf{4}$ & $\mathbf{5}$ & $\mathbf{6}$ & $\mathbf{7}$ \\
\hline $\begin{array}{l}\text { Cusp } \\
\text { Angle }\end{array}$ & $69.52(7.48)^{6,7}$ & $69.53(4.86)^{6,7}$ & $77.09(4.344)^{6,7}$ & $99.24(13.81)^{7}$ & $110.69(22.54)^{2,3,4,7}$ & $159.52(11.55)^{2,3,4,5,6}$ \\
Crown & $11.16(0.28)^{5,6,7}$ & $10.3(0.34)^{5,6,7}$ & $9.60(0.80)^{6,7}$ & $7.67(1.64)^{2,3,7}$ & $6.99(1.29)^{2,3,4,7}$ & $4.06(0.98)^{2,3,4,5,6}$ \\
Height & & & & & & \\
\hline
\end{tabular}




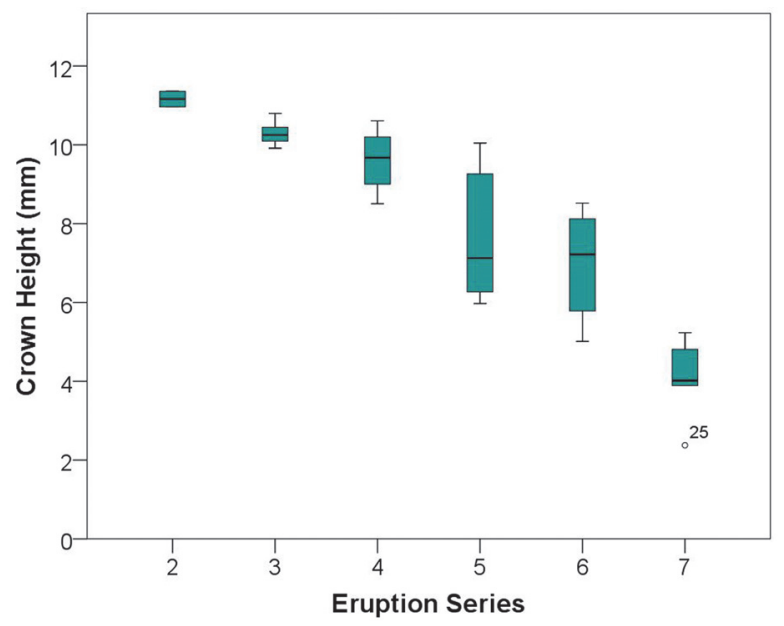

FIGURE 5. Boxplot of crown heights of the $\mathrm{m} 1$ protoconid for each eruption series of Tapirus polkensis from the Gray Fossil Site. Bars represent mean values, boxes represent interquartile ranges, and whiskers represent maximum and minimum values.

were also significantly different from ES 6. Crown height appears to follow a steady decline through all Eruption Series with the sharpest decline being present between Eruption Series 6 and 7 (Figure 5). The standard deviation between crown heights in each eruption series was very low, ranging from 1.64 in ES 5 to 0.28 in ES 2.

Linear regression showed a strong negative correlation between tooth crown height and cusp angle $\left(r^{2}=0.868\right)$ (Figure 6$)$. Cusp angle steadily increased as crown height decreased in every Eruption Series. This is to be expected as the cusp changes from sharp to round to blunt and eventually becomes completely worn down.

\section{DISCUSSION}

Tapirs (Tapirus polkensis) at the Gray Fossil Site maintained a relatively consistent wear gradient throughout their lifetime (Figure 6). Some individuals retained relatively unworn tooth crowns and sharp cusp angles into adulthood (ES 5 and ES 6). This is consistent with the findings of previous studies, where brachydont browsing ungulates showed lower mesowear rates (Rivals et al., 2007). Within the Rivals et al. (2007) study, the brachydont primitive ruminant artiodactyl, Leptomeryx, showed a similar pattern of persistent wear rate, whereas mesodont and hypsodont artiodactyls showed more variable rates of wear at different age stages. Our findings are in agreement with Fortelius and Solounias (2000) and Rivals et al. (2007) in that wear rates are stable throughout

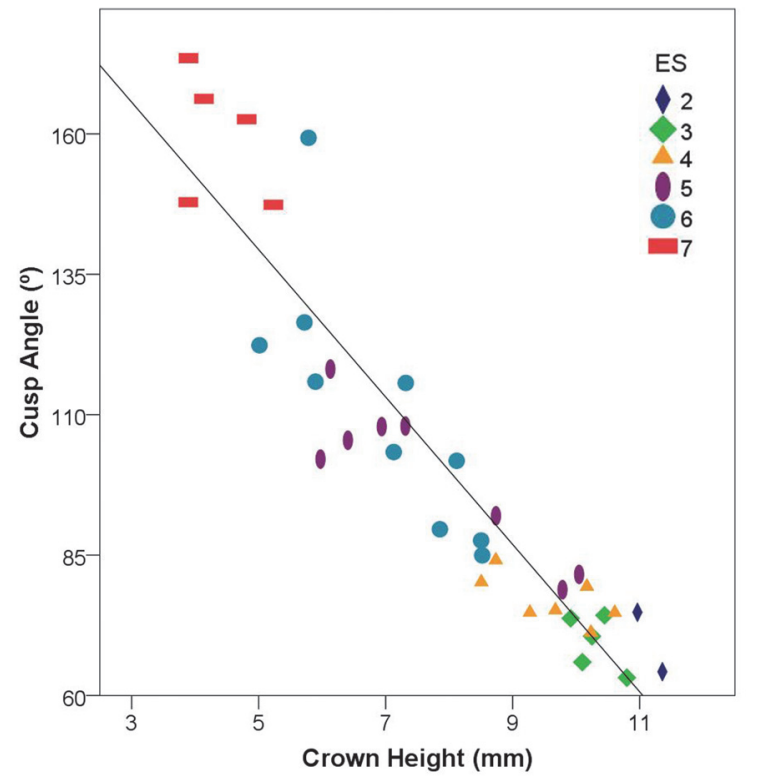

FIGURE 6. Scatter plot of $\mathrm{m} 1$ protoconid cusp angle versus crown height for specimens in each eruption series (ES) of Tapirus polkensis from the Gray Fossil Site. The line represents a least squares linear regression of these data, regression equation: $\mathrm{m} 1 \mathrm{CA}=20.5-$ 13.13 $(\mathrm{m} 1 \mathrm{H})$, correlation coefficient, $r=0.932$.

most of life except when examining the early and late stages, shown here through eruption series. Lowland tapirs (Tapirus terrestris) consume a variety of plants and fruit from trees, palms, and lianas and have been seen pulling down on branches and stems of saplings while browsing (Salas and Fuller, 1996). Similarly, diets of the mountain tapir (Tapirus pinchaque) and Baird's tapir (Tapirus bairdii) follow that of a typical browser, consisting of a variety of trees, herbs, shrubs, berries, and twigs with a wide diversity of plant species being consumed (Downer, 2001; Tobler, 2002). Relative abundance of these plants in the composition of their diet varies depending on the habitat and the availability of each species (Tobler, 2002). Given the predicted similarity in browsing diets between modern tapirs and Tapirus polkensis, similar mesowear scores would be expected when examining extant populations with minor differences between populations due to varying plant abundances.

This finding also helps support and fortify the findings of DeSantis and Wallace (2008), who interpreted the Gray Fossil Site as a dense forest with relatively stable climate and temperature. As is to be expected in browsers from wet environments, the mean mesowear score of the entire population is relatively low (cusp angle $=101.64$, crown height $=7.80$ ), which is comparable to a 
mesowear score of 1 on the Mihlbachler et al. (2011) scale. When looking at just the mature adult population (ES 5 specimens with an erupted M3, ES 6, and 7) the mesowear score is relatively low (cusp angle $=124.55$, crown height $=6.01 \mathrm{~mm}$ ), suggesting there were relatively low levels of tooth wear from ingested grit (Mihlbachler et al., 2011). Dentine exposure in all teeth did not occur until individuals were around 9 years old (ES 7). If dentine appeared earlier in life, it would indicate that these individuals were subsisting on vegetation that their dentition could not sustain through old age. No young individuals were found with completely worn and flattened teeth, consistent with a steady flattening of the tooth crown through an individual's life. With cusp angles and crown heights being highly correlated and all individuals of similar age falling close together, a relatively uniform diet can be inferred across the population with no large variation between individuals and wear rates. Interpretation of this population as having a browsing diet is consistent with these results being comparable for mesowear scores for modern browsing ungulates (Mihlbachler et al., 2011) and Paleogene equids which inhabited warm, wet environments; each of these groups contrasts with modern grazing ungulates and Neogene and Quaternary equids that inhabited cooler, more arid environments dominated by grasses.

The population structure of tapirs at the GFS primarily yields mature individuals (Figure 7).

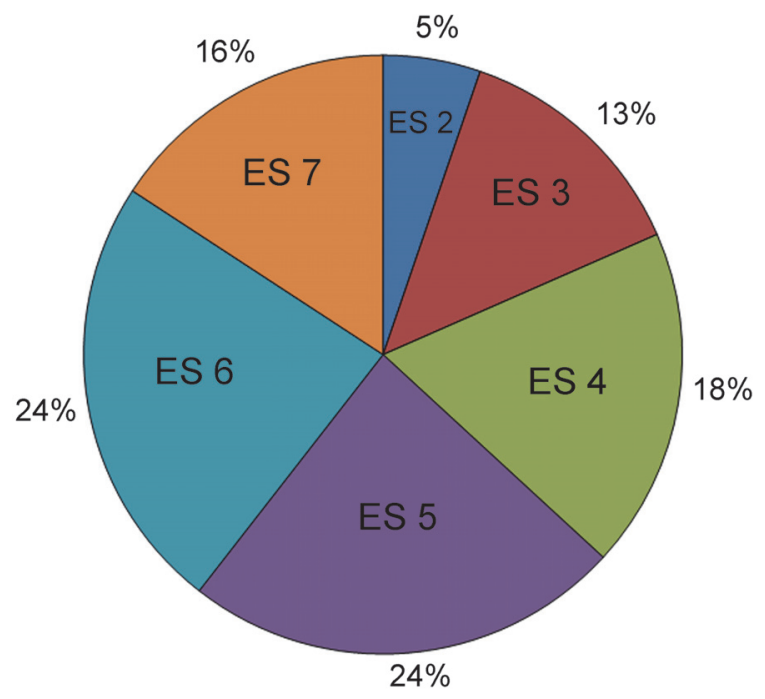

FIGURE 7. Pie chart representing the sampled population structure of Tapirus polkensis at the Gray Fossil Site, indicated by percentage of specimens in each eruption series (ES).
Approximately 32 percent of the individuals able to be measured for this study were categorized in the last two Eruption Series, followed by another 19 percent being in Eruption Series 5. These results may indicate the population was able to sustain itself and there was survival of older individuals. Taphonomic studies of individual deaths in the level of the species or population are a useful tool to better understand the ecology of the area, what the population demographics mean, why the species were there, and what eventually led to their death (Lyman, 1994; Rogers et al., 2007; Mihlbachler et al., 2018). Mihlbachler et al. (2018) recently examined microwear and mesowear in mass death assemblages demonstrating how ecological stress can be documented in dental morphology. A taphonomic examination of the Gray Fossil Site suggests the tapir specimens built up from attrition, rather than a die-off event leading to mass mortality (Hulbert et al., 2009). With isotopic analysis recording little seasonal temperature and precipitation fluctuation, it does not seem likely that seasonal stresses at the site led to tapir death either. Both factors support evidence that the Gray Fossil Site was a gradual accumulation that was able to sustain long-standing populations rather than a mass death assemblage. It is also worth mentioning that fossils from older individuals may be preferentially recovered due to preservation biases (Behrensmeyer, 1988; Lyman, 1994), as their skeletons are fully formed and not as brittle as bones from younger individuals.

Multiple mesowear analyses have been conducted previously on a variety of perissodactyls; however, tapirs were not part of those analyses (Fortelius and Solounias, 2000; Kaiser et al., 2000; Mihlbachler et al., 2011). These analyses have all based their methods on Fortelius and Solounias (2000), placing specimen into categorical mesowear groups. As the molars of tapirs are not easily comparable to these groups due to their bilophodont molar morphology, and given that the previous studies were not analyzing a population structure from juvenile to adult, a new method for mesowear was applied to this study. By simply using the angle in degrees for cusp angle and comparing the variation between Eruption Series, we were able to examine a more exact wear gradient. Studies of continental populations of specific ungulates and comparisons between multiple groups of ungulates (browsers, grazers) can benefit from examination of broad mesowear categories, which can show general temporal trends among taxa with brachydont to hypsodont dentition and how 
increased crown height is associated with higher mesowear scores (Rivals et al., 2007; Mihlbachler et al., 2011; Fraser et al., 2014; Maguire, 2015). However, for a local population analysis, examination of more specific changes in cusp angles can be beneficial. Loffredo and DeSantis (2014) employed several different methodologies for examining dental mesowear in the equid Cormohipparion emsliei, including the numerical scale used by most studies (referred to therein as MNS), but also several cusp-specific measurements like cusp angle, cusp area, intercusp distance, and occlusal relief. Their measurement of cusp angle was similar to the one used here, but was applied to upper cheek teeth rather than lowers (Loffredo and DeSantis, 2014). They found significant relationships between cusp angle and MNS, suggesting cusp angle is appropriate for measuring mesowear and interpreting diets of extinct populations (Loffredo and DeSantis, 2014). It is important to note, however, that the Loffredo and DeSantis (2014) study did not directly compare mesowear metrics to overall measurements of crown height or ontogeny, as was done here. Thus, direct comparison of the results of these two studies is not possible.

Detailed study of the population structure of Tapirus polkensis at the Gray Fossil Site has provided new insight into how the dentition of these dwarf tapirs changed throughout their lifetime. While there are not currently any comparable tapir populations, potential future discoveries could aid in estimating just how influential the environment was on tapir dentition. The extension of this methodology to modern tapirs could offer comparisons to see how tapir environmental preference has changed since the Pliocene and whether the wear gradient has remained constant or if it has increased/decreased over time. Future directions for mesowear analysis of this large population could examine the wear of the molars in greater detail, allowing testing of ontogenetic dietary signal and whether diet is consistent throughout lifetime in addition to rates of wear. Such methods have been used to examine proboscideans and xenarthrans, where measured angles from worn tooth surfaces, such as facets and dentine pits, have been used to study dietary changes through an individual's lifetime (Saarinen et al., 2015; Saarinen and Karme, 2017).

\section{CONCLUSIONS}

Results from this study allow an analysis of mesowear in a tapir population unmatched in size by any other site. A gradual flattening of cusps is shown from individuals approximately one to 11 years old with a large number of individuals persisting into old adult age. Gradual flattening is consistent with what is to be expected in most browsers that can be examined today, with flattening occurring at later stages of life than is seen in grazers. Correlation between cusp angle and crown height was consistent throughout all stages of eruption and significant differences between cusp angle means of each eruption series highlights the gradual nature of tooth wear within this population. These findings provide additional support for the paleoecological setting of the GFS as a wet and stable environment interpreted from past studies. This study was also able to reexamine the mesowear methodology used in past studies of ungulates and provide a new measure of tapir tooth shape using an exact cusp angle, which will facilitate present and future comparisons.

\section{ACKNOWLEDGMENTS}

Specimen collection at the Gray Fossil Site was partially funded through a National Science Foundation Grant (NSF Grant \#0958985) to S.C. Wallace and B.W. Schubert. A. Nye, at the East Tennessee State University Museum of Natural History, kindly facilitated access to collections and offered assistance while collecting data and photographing specimens. We would also like to thank the reviewers for their comments and suggestions, which helped improve the quality of this manuscript.

\section{REFERENCES}

Andrews, P. and Hixson, S. 2014. Taxon-free methods of palaeoecology. Annales Zoologici Fennici, 51:269-284. https://doi.org/10.5735\%2F086.051.0225

Behrensmeyer, A.K. 1988. Fossils in the Making: Vertebrate Taphonomy and Paleoecology. University of Chicago Press, Chicago, Illinois. 
Boardman, G.S. and Schubert, B.W. 2011. First Mio-Pliocene salamander fossil assemblage from the southern Appalachians. Palaeontologia Electronica, 14.2.16A:19p. https://palaeo-electronica.org/2011_2/257/index.html

Bourque, J.R. and Schubert, B.W. 2015. Fossil musk turtles (Kinosternidae, Sternotherus) from the late Miocene-early Pliocene (Hemphillian) of Tennessee and Florida. Journal of Vertebrate Paleontology, 35:e885441. https://doi.org/10.1080\%2F02724634.2014.885441

Brandon, S. 2013. Discovery of Bald Cypress Fossil Leaves at the Gray Fossil Site, Tennessee and Their Ecological Significance. Unpublished Undergraduate Honors Thesis, East Tennessee State University, Johnson City, Tennessee, USA.

Butler, K., Louys, J., and Travouillon, K. 2014. Extending dental mesowear analyses to Australian marsupials, with applications to six Plio-Pleistocene kangaroos from southeast Queensland. Palaeogeography, Palaeoclimatology, Palaeoecology, 408:11-25. https:// doi.org/10.1016/j.palaeo.2014.04.024

Cozzuol, M.A., Clozato, C., Holanda, E., Rodrigues, F.H., Nienow, S., de Thoisy, B., Redondo, R.A., and Santos, F.R. 2013. A new species of tapir from the Amazon. Journal of Mammalogy, 94:1331-1345. https://doi.org/10.1644/12-MAMM-A-169.1

Crowe, C. 2017. Sciurids (Rodentia: Sciuridae) of the Late Mio-Pliocene Gray Fossil Site and the Late Miocene Tyner Farm: Implications on Ecology and Expansion of the Sciurid Record. Unpublished Master's Thesis, East Tennessee State University, Johnson City, Tennessee, USA.

Damuth, J. and Janis, C.M. 2014. A comparison of observed molar wear rates in extant herbivorous mammals. Annales Zoologici Fennici, 51:188-200. https://doi.org/ 10.5735\%2F086.051.0219

Danowitz, M., Hou, S., Mihlbachler, M., Hastings, V., and Solounias, N. 2016. A combinedmesowear analysis of late Miocene giraffids from North Chinese and Greek localities of the Pikermian Biome. Palaeogeography, Palaeoclimatology, Palaeoecology, 449:194-204. https:/ /doi.org/10.1016/j.palaeo.2016.02.026

DeSantis, L.R. and Wallace, S.C. 2008. Neogene forests from the Appalachians of Tennessee, USA: geochemical evidence from fossil mammal teeth. Palaeogeography,

Palaeoclimatology, Palaeoecology, 266:59-68. https://doi.org/ 10.1016\%2Fj.palaeo.2008.03.032

Downer, C.C. 2001. Observations on the diet and habitat of the mountain tapir (Tapirus pinchaque). Journal of Zoology, 254:279-291. https://doi.org/ $10.1017 \% 2 F s 0952836901000796$

Edwards, E.J., Osborne, C.P., Strömberg, C.A., Smith, S.A., and C4 Grasses Consortium. 2010. The origins of $\mathrm{C} 4$ grasslands: integrating evolutionary and ecosystem science. Science, 328:587-591. https://doi.org/10.1126\%2Fscience.1177216

Evans, A.R., Wilson, G.P., Fortelius, M., and Jernvall, J. 2007. High-level similarity of dentitions in carnivorans and rodents. Nature, 445(7123):78. https://doi.org/10.1038\%2Fnature05433

Fortelius, M. and Solounias, N. 2000. Functional characterization of ungulate molars using the abrasion-attrition wear gradient: a new method for reconstructing paleodiets. American Museum Novitates, 3301:1-36. https://doi.org/10.1206/00030082(2000)301<0001:FCOUMU>2.0.CO;2

Fraser, D., Zybutz, T., Lightner, E., and Theodor, J.M. 2014. Ruminant mandibular tooth mesowear: a new scheme for increasing paleoecological sample sizes. Journal of Zoology, 294:41-48. https://doi.org/10.1111/jzo.12149

Gibson, M.L. 2011. Population structure based on age-class distribution of Tapirus polkensis from the gray fossil site, Tennessee. Unpublished Doctoral Dissertation, East Tennessee State University, Johnson City, Tennessee, USA.

Green, J.L. and Croft, D.A. 2018. Using dental mesowear and microwear for dietary inference: a review of current techniques and applications, p. 53-73. In Croft, D.A., Su, D.F., and Simpson, S.W. (eds.), Methods in Paleoecology: Reconstructing Cenozoic Terrestrial Environments and Ecological Communities, Vertebrate Paleobiology and Paleoanthropology, Springer International Publishing, Cham, Switzerland. https://doi.org/10.1007/978-3-31994265-0_5

Hoffman, J.M., Fraser, D., and Clementz, M.T. 2015. Controlled feeding trials with ungulates: a new application of in vivo dental molding to assess the abrasive factors of microwear. Journal of Experimental Biology, 218:1538-1547. https://doi.org/10.1242\%2Fjeb.118406 
Hofmann, R.R. and Stewart, D.R.M. 1972. Grazer or browser: a classification based on the stomach-structure and feeding habits of East African ruminants. Mammalia, 36:226-240. https://doi.org/10.1515/mamm.1972.36.2.226

Hulbert, R.C. 2005. Late Miocene Tapirus (Mammalia, Perissodactyla) from Florida, with description of a new species, Tapirus webbi. Bulletin of the Florida Museum of Natural History, 45(4):465-494.

Hulbert, R.C. 2010. A new early Pleistocene tapir (Mammalia: Perissodactyla) from Florida, with a review of Blancan tapirs from the state. Bulletin Florida Museum Natural History, 49:67126.

Hulbert, R.C., Wallace, S.C., Klippel, W.E., and Parmalee, P.W. 2009. Cranial morphology and systematics of an extraordinary sample of the late Neogene dwarf tapir, Tapirus polkensis (Olsen). Journal of Paleontology, 83:238-262. https://doi.org/10.1666\%2F08-062.1

Janis, C.M. 1988. An estimation of tooth volume and hypsodonty indices in ungulate mammals, and the correlation of these factors with dietary preferences, p. 367-387. In Russell, D.E., Santoro, J.-P., and Sigogneau-Russell, D. (eds.), Teeth Revisited: Proceedings of the VIIth International Symposium on Dental Morphology, Paris, 1986. Mémoires du Muséum National d'histoire Naturelle, Paris (serie C), 53:367-387.

Janis, C.M. 1995. Correlation between craniodental morphology and feeding behavior in ungulates: reciprocal illumination between living and fossil taxa, p. 76-98. In Thomason, J.J. (ed.) Functional Morphology in Vertebrate Paleontology. Cambridge University Press, Cambridge.

Jasinski, S.E. 2013. Fossil Trachemys (Testudines: Emydidae) from the Late Hemphillian of Eastern Tennessee and Its Implications for the Evolution of the Emydidae. Unpublished Masters Thesis, East Tennessee State University, Johnson City, Tennessee, USA.

Kaiser, T.M., Solounias, N., Fortelius, M., Bernor, R.L., and Schrenk, F. 2000. Tooth mesowear analysis on hippotherium primigenium from the Vallesian Dinotheriensande (Germany). Carolinea: Beiträge zur naturkundlichen Forschung in Südwestdeutschland, 58:103-114.

Loffredo, L.F. and DeSantis, L.R. 2014. Cautionary lessons from assessing dental mesowear observer variability and integrating paleoecological proxies of an extreme generalist Cormohipparion emsliei. Palaeogeography, Palaeoclimatology, Palaeoecology, 395:42-52. https://doi.org/10.1016/j.palaeo.2013.12.020

Lyman, R.L. 1994. Vertebrate Taphonomy. Cambridge University Press, Cambridge.

Macdonald, D.W. 1985. The Encyclopedia of Mammals. Oxford University Press, New York.

Markwick, P.J. 1998. Fossil crocodilians as indicators of Late Cretaceous and Cenozoic climates: implications for using palaeontological data in reconstructing palaeoclimate. Palaeogeography, Palaeoclimatology, Palaeoecology, 137:205-271. https://doi.org/ $10.1016 \% 2 F s 0031-0182 \% 2897 \% 2900108-9$

Maguire, K.C. 2015. Dietary niche stability of equids across the mid-Miocene Climatic Optimum in Oregon, USA. Palaeogeography, Palaeoclimatology, Palaeoecology, 426:297-307. https:// doi.org/10.1016/j.palaeo.2015.03.012

Mead, J.I., Schubert, B.W., Wallace, S.C., and Swift, S.L. 2012. Helodermatid lizard from the Mio-Pliocene oak-hickory forest of Tennessee, eastern USA, and a review of monstersaurian osteoderms. Acta Palaeontologica Polonica, 57:111-121. https://doi.org/ 10.4202\%2Fapp.2010.0083

Mendoza, M., Janis, C.M., and Palmqvist, P. 2002. Characterizing complex craniodental patterns related to feeding behaviour in ungulates: a multivariate approach. Journal of Zoology, 258:223-246. https://doi.org/10.1017\%2Fs0952836902001346

Mihlbachler, M.C., Rivals, F., Solounias, N., and Semprebon, G.M. 2011. Dietary change and evolution of horses in North America. Science, 331:1178-1181. https://doi.org/ 10.1126\%2Fscience. 1196166

Mihlbachler, M.C., Campbell, D., Chen, C., Ayoub, M., and Kaur, P. 2018. Microwear-mesowear congruence and mortality bias in rhinoceros mass-death assemblages. Paleobiology, 44:131-154. https://doi.org/10.1017\%2Fpab.2017.13

Ochoa, D., Whitelaw, M., Liu, Y.S., and Zavada, M. 2012. Palynology from Neogene sediments at the Gray Fossil Site, Tennessee, USA: Floristic implications. Review of Palaeobotany and Palynology, 184:36-48. https://doi.org/10.1016\%2Fj.revpalbo.2012.03.006 
Ochoa, D., Zavada, M.S., Liu, Y., and Farlow, J.O. 2016. Floristic implications of two contemporaneous inland upper Neogene sites in the eastern US: Pipe Creek Sinkhole, Indiana, and the Gray Fossil Site, Tennessee (USA). Palaeobiodiversity and Palaeoenvironments, 96:239-254. https://doi.org/10.1007\%2Fs12549-016-0233-4

Olsen, S.J. 1960. Age and faunal relationships of Tapiravus remains from Florida. Journal of Paleontology, 34:164-167.

Parmalee, P.W., Klippel, W.E., Meylan, P.A., and Holman, J.A. 2002. A late Miocene-early Pliocene population of Trachemys (Testundines: Emydidae) from east Tennessee. Annals Carnegie Museum, 71:233-239

Rasband, W.S. 2016. ImageJ, U. S. National Institutes of Health, Bethesda, Maryland, USA, https://imagej.nih.gov/ij/, 1997-2016.

Retallack, G.J. 2007. Cenozoic paleoclimate on land in North America. The Journal of Geology, 115:271-294. https://doi.org/10.1086\%2F512753

Rogers, R.R., Eberth, D.A., and Fiorillo, A.R. (eds.). 2007. Bonebeds: Genesis, Analysis, and Paleobiological Significance. University of Chicago Press, Chicago.

Rivals, F., Mihlbachler, M.C., and Solounias, N. 2007. Effect of ontogenetic-age distribution in fossil and modern samples on the interpretation of ungulate paleodiets using the mesowear method. Journal of Vertebrate Paleontology, 27:763-767. https://doi.org/10.1671/02724634(2007)27[763:EOODIF]2.0.CO;2

Ruiz-García, M., Castellanos, A., Agueda Bernal, L., Pinedo-Castro, M., Kaston, F., and Shostell, J.M. 2016. Mitogenomics of the mountain tapir (Tapirus pinchaque, Tapiridae, Perissodactyla, Mammalia) in Colombia and Ecuador: Phylogeography and insights into the origin and systematics of the South American tapirs. Mammalian Biology, 81:163-175.

Saarinen, J. and Karme, A. 2017. Tooth wear and diets of extant and fossil xenarthrans (Mammalia, Xenarthra)-applying a new mesowear approach. Palaeogeography, Palaeoclimatology, Palaeoecology, 476:42-54. https://doi.org/10.1016/j.palaeo.2017.03.027

Saarinen, J., Karme, A., Cerling, T., Uno, K., Säilä, L., Kasiki, S., Ngene, S., Obari, T., Mbua, E., Manthi, F.K., and Fortelius, M. 2015. A new tooth wear-based dietary analysis method for Proboscidea (Mammalia). Journal of Vertebrate Paleontology, 35(3): e918546. https:// doi.org/10.1080/02724634.2014.918546

Saarinen, J. and Lister, A.M. 2016. Dental mesowear reflects local vegetation and niche separation in Pleistocene proboscideans from Britain. Journal of Quaternary Science, 31:799-808. https://doi.org/10.1002/jqs.2906

Salas, L.A. and Fuller, T.K. 1996. Diet of the lowland tapir (Tapirus terrestris L.) in the Tabaro River valley, southern Venezuela. Canadian Journal of Zoology, 74:1444-1451. https:// doi.org/10.1139\%2Fz96-159

Samuels, J.X., Bredehoeft, K.E., and Wallace, S.C. 2018. A new species of Gulo from the Early Pliocene Gray Fossil Site (Eastern United States); rethinking the evolution of wolverines. PeerJ, 6:e4648. https://doi.org/10.7717/peerj.4648

Shunk, A.J., Driese, S.G., and Clark, G.M. 2006. Latest Miocene to earliest Pliocene sedimentation and climate record derived from paleosinkhole fill deposits, Gray Fossil Site, northeastern Tennessee, USA. Palaeogeography, Palaeoclimatology, Palaeoecology, 231:265-278. https://doi.org/10.1016\%2Fj.palaeo.2005.08.001

Shunk, A.J., Driese, S.G., and Dunbar, J.A. 2009. Late Tertiary paleoclimatic interpretation from lacustrine rhythmites in the Gray Fossil Site, northeastern Tennessee, USA. Journal of Paleolimnology, 42:11-24. https://doi.org/10.1007\%2Fs10933-008-9244-0

Solounias, N., Tariq, M., Hou, S., Danowitz, M., and Harrison, M. 2014. A new method of tooth mesowear and a test of it on domestic goats. Annales Zoologici Fennici, 51:111-118. https:// www.jstor.org/stable/23737195

Strömberg, C.A. 2011. Evolution of grasses and grassland ecosystems. Annual Review of Earth and Planetary Sciences, 39:517-544. https://doi.org/10.1146\%2Fannurev-earth-040809152402

Tobler, M.W. 2002. Habitat use and diet of Baird's tapirs (Tapirus bairdii) in a montane cloud forest of the Cordillera de Talamanca, Costa Rica. Biotropica, 34:468-474. https://doi.org/ 10.1111/j.1744-7429.2002.tb00563.x

Ulbricht, A., Maul, L.C., and Schulz, E. 2015. Can mesowear analysis be applied to small mammals? A pilot-study on leporines and murines. Mammalian Biology-Zeitschrift für Säugetierkunde, 80:14-20. https://doi.org/10.1016\%2Fj.mambio.2014.06.004 
Ungar, P.S. 2015. Mammalian dental function and wear: A review. Biosurface and Biotribology, 1:25-41. https://doi.org/10.1016\%2Fj.bsbt.2014.12.001

Van Valkenburgh, B. 1989. Carnivore dental adaptations and diet: a study of trophic diversity within guilds, p. 410-436. In Gittleman, J.L. (ed.), Carnivore Behavior, Ecology, and Evolution. Springer, Boston. https://doi.org/10.1007\%2F978-1-4613-0855-3_16

Wallace, S.C. and Wang, X. 2004. Two new carnivores from an unusual late Tertiary forest biota in eastern North America. Nature, 431:556. https://doi.org/10.1038\%2Fnature02819

Wilson, D.E. and Reeder, D.M. (eds.). 2005. Mammal Species of the World: A Taxonomic and Geographic Reference. Vol. 2. JHU Press, Baltimore.

Worobiec, E., Liu, Y., and Zavada, M.S. 2013. Palaeoenvironment of late Neogene lacustrine sediments at the Gray Fossil Site, Tennessee, U.S.A. Annales Societatis Geologorum Poloniae, 83:51-63.

Zobaa, M.K., Zavada, M.S., Whitelaw, M.J., Shunk, A.J., and Oboh-lkuenobe, F.E. 2011. Palynology and palynofacies analyses of the Gray Fossil Site, eastern Tennessee: Their role in understanding the basin-fill history. Palaeogeography, Palaeoclimatology, Palaeoecology, 308:433-444. https://doi.org/10.1016\%2Fj.palaeo.2011.05.051 
APPENDIX 1.

Full table of specimens and their corresponding eruption series.

\begin{tabular}{|c|c|}
\hline Specimen ID & Eruption Series \\
\hline ETMNH 605 & 2 \\
\hline ETMNH 3687 & 2 \\
\hline ETMNH 600 & 3 \\
\hline ETMNH 3694 & 3 \\
\hline ETMNH 3720 & 3 \\
\hline ETMNH 3808 & 3 \\
\hline ETMNH 12729 & 3 \\
\hline ETMNH 3695 & 4 \\
\hline ETMNH 3699 & 4 \\
\hline ETMNH 4144 & 4 \\
\hline ETMNH 611 & 4 \\
\hline ETMNH 7280 & 4 \\
\hline ETMNH 7899 & 4 \\
\hline ETMNH 5172 & 4 \\
\hline ETMNH 3426 & 5 \\
\hline ETMNH 3712 & 5 \\
\hline ETMNH 5171 & 5 \\
\hline ETMNH 12980 & 5 \\
\hline ETMNH 20488 & 5 \\
\hline ETMNH 15741 & 5 \\
\hline ETMNH 10618 & 5 \\
\hline ETMNH 18602 & 5 \\
\hline ETMNH 20995 & 5 \\
\hline ETMNH 608 & 6 \\
\hline ETMNH 682 & 6 \\
\hline ETMNH 687 & 6 \\
\hline ETMNH 3573 & 6 \\
\hline ETMNH 3719 & 6 \\
\hline ETMNH 10383 & 6 \\
\hline ETMNH 3710 & 6 \\
\hline ETMNH 13047 & 6 \\
\hline ETMNH 9776 & 6 \\
\hline ETMNH 3519 & 7 \\
\hline ETMNH 3716 & 7 \\
\hline ETMNH 3717 & 7 \\
\hline ETMNH 5285 & 7 \\
\hline ETMNH 17659 & 7 \\
\hline ETMNH 14921 & 7 \\
\hline
\end{tabular}

